\title{
Entrepreneurial orientation, assessment and management of projects and impact in corporate entrepreneurship: intention to action
}

\section{Orientación emprendedora, evaluación y gestión de proyectos e impactos en el emprendimiento corporativo: De la intención a la acción}

\author{
Raúl Armando Cardona Montoya ${ }^{1}$ \\ IzAIAS MARTINS ${ }^{2}$ \\ Hermilson Velásquez Ceballos ${ }^{1}$ \\ Universidad EAFIT (Colombia)
}

Recibido el 27 de noviembre de 2014, aceptado el 6 de junio de 2016

Publicado online el 25 de enero de 2017

$\mathrm{N}^{\mathrm{o}}$ de clasificación JEL: M100

DOI: $10.5295 / \mathrm{cdg} .140511 \mathrm{rc}$

\begin{abstract}
:
Corporate entrepreneurship remains a phenomenon under study due to the positive impact it has generated, first of all, over companies, strengthening their competitive advantages and increasing their value. Secondly, it contributes to the macroeconomic dynamism that occurs in nations in terms of growth, employment, income, innovation and competitiveness.

Focusing on Theories of Corporate Entrepreneurship and Resources and Capabilities, the aim of this paper is to relate the entrepreneurial orientation as intention to corporate entrepreneurship as action, considering their differences and complementarities. The database used for empirical confrontation comes from the survey of 137 SME in the Colombian manufacturing sector. Multivariate analysis models and structural equations were estimated, and quantitative evidence of direct and positive relationships with both phenomena indirectly mediated by the capability to assess and manage projects will be presented. This capability has been little explored in previous studies and not proven in relation to the phenomenon analyzed. The results of the factor analysis suggest that this capability can be considered as a theoretical construct, adding theoretical developments with respect to previous studies which have included and analyzed other capabilities.
\end{abstract}

Keywords:

Entrepreneurial orientation, corporate entrepreneurship, resource based view, theory planned behaviour, capability to assess and manage projects.

\footnotetext{
1 Escuela de Economía y Finanzas de la Universidad EAFIT, Carrera 49 N 7 Sur-50, Medellin (Colombia). rcardona@eafit.edu.co; evelas@eafit.edu.co

2 Escuela de Administración de la Universidad EAFIT, Carrera 49 Nº 7 Sur-50, Medellin (Colombia). imartins@ eafit.edu.co
} 


\section{Resumen:}

El emprendimiento corporativo sigue siendo un fenómeno en estudio debido a los impactos positivos que genera para las compañías en el logro de ventajas competitivas e incremento del valor, así como por el dinamismo macroeconómico que produce para las naciones en términos de crecimiento, empleo, ingresos, innovación y competitividad. Con enfoque en las teorías del Emprendimiento Corporativo y de Recursos y Capacidades, el objetivo de este trabajo es relacionar la orientación emprendedora como intención, con el emprendimiento corporativo como acción, considerando la diferencia en sus significados y su complementariedad. La base de datos usada para la contrastación empírica, proviene de la encuesta realizada a 137 PYMEs del sector manufacturero en Colombia. Se estiman modelos de análisis multivariante y ecuaciones estructurales, y se presenta evidencia cuantitativa de la relación directa y positiva que tienen ambos fenómenos y de forma indirecta, mediada por la capacidad de evaluar y gestionar proyectos; esta rutina ha sido poco explorada en estudios previos y no contrastada en relación al fenómeno analizado. Los resultados del análisis factorial, permiten integrar y proponer la capacidad como constructo teórico, avanzando con respecto a estudios previos del fenómeno, que han incluido y analizado otras capacidades.

\section{Palabras clave:}

Orientación emprendedora, emprendimiento corporativo, teoría de recursos y capacidades, teoría del comportamiento planificado, capacidad de evaluar y gestionar proyectos. 


\section{INTRODUCTION}

Productivity and innovation demands for the global competitiveness and the recovery from international economic crises are key factors that challenge firms to the corporative entrepreneurship (CE) by promoting strategies and structuring of resources and capabilities (Zahra 1991; Moreno and Casillas 2008; Ireland et al. 2009; Kuratko and Audretsch 2009).

The studies on CE keep on increasing and the relationships analyzed continue focusing on the importance of this phenomenon in both the entrepreneurial transformation and the economic dynamism. After finishing the seminal works on entrepreneurial orientation (EO), Miller (2011), Covin and Lumpkin (2011) and Bouchard and Basso (2011), reflected on the importance that the development and complementarity with the CE processes when structuring special capabilities (Barney, 1991). The main goal of this work is to analyze the few contrasted relationships between the EO and the CE which are studied individually since they are considered synonyms (Lumpkin and Dess 1996; Antoncic and Hisrich 2001; Urbano et al. 2010). Another goal of this work is to validate the indirect relationship between EO and CE mediated by the capability of assessing and managing projects.

To attain the main goals, it is essential, first, to differentiate the meaning of constructs that come from the analysis made by different authors and contrast their relationship of complementarity by using theoretical propositions stated by Bouchard and Basso (2011) about the direct and positive relationships between the EO and the $\mathrm{CE}$. For instance, there are two recent studies which found positive relationships between intention-action: Hasan et al. (2013) and Gelderen et al. (2015) under CE perspectives and venture creation respectively.

Second, previous work have focused on the capabilities that boost CE. This study will focus on the capability of assessing and managing projects which, as reviewed in the literature, have not been studied in depth as a determinant factor of the two phenomena under study. However, this capability has been developed as a specialization within management and, have challenged future research work in CE (Goodale et al. 2011; Corbett et al. 2013).

This study focuses on CE, Resources Based View - RBV (Barney, 1991), and project theories. Using Stata 13, we followed a quantitative approach based upon multivariate analysis techniques, more specifically, factorial analysis and structural equation models that represent, contrast empirically, and explain the relationships proposed by the theoretical framework between the different phenomena to be studied.

One hundred and thirty seven SME from the manufacturing sector were surveyed in Medellin - Colombia. This country is known as one of those whose reforms have boosted in the last couple of years, by restructuring public policies that promote the entrepreneurship and competitiveness of the SME and by improving its innovative endeavors (Banco Mundial-Doing Business 2015a).

After introducing the study, we will present the theoretical framework, followed by the methodology and the achievement of the goals proposed. Afterwards, we will present the statistical model used and the validation of the hypothesis. Finally, conclusions and discussion are given to summarize the article. 


\section{LITERATURE REVIEW}

Several studies have analyzed the precedents and consequences of CE (Table 1). For example, when carrying out empirical studies, there have been some hypotheses and findings concerning the phenomenon itself and its positive impacts on the entrepreneurial endeavors both external and internal factors, the latter based upon the RBV.

Table 1

\section{CE internal and external antecedent factors}

\begin{tabular}{|c|c|c|}
\hline Author & Factor & Approach \\
\hline $\begin{array}{l}\text { Covin and Slevin (1991); Zahra (1991, 1993); } \\
\text { Lumpkin and Dess (2001); Martins et al. (2012); } \\
\text { Martins and Rialp (2013); Álvarez and Urbano } \\
\text { (2011) }\end{array}$ & External factors & $\begin{array}{l}\text { Environmental variables and } \\
\text { competitive rivalry. }\end{array}$ \\
\hline $\begin{array}{l}\text { Burgelman, (1983); Stevenson and Jarillo, } \\
\text { (1990); Mintzberg, (1994); Dess and Lumpkin } \\
\text { (2005); Ireland et al. (2009); Kuratko, (2007); } \\
\text { Moreno and Casillas, (2008); Kuratko and Au- } \\
\text { dretsch, (2009); Goodale et al. (2011); Lechner } \\
\text { and Gudmundsson, (2014); Kuratko et al. (2014) }\end{array}$ & Internal Factors & $\begin{array}{l}\text { Entrepreneurial strategy, in- } \\
\text { ternal processes, CE strategy. } \\
\text { Position towards proacti- } \\
\text { vity to take advantage of } \\
\text { the market opportunities, } \\
\text { willingness to innovation, } \\
\text { assumptions of the risks. }\end{array}$ \\
\hline $\begin{array}{l}\text { Zahra and George, (2002); Wiklund and She- } \\
\text { pherd, (2003); McGrath et al. (1995) } \\
\text { Kreiser, P. M. (2011); McGrath, R. G. (2001) }\end{array}$ & Internal Factors & $\begin{array}{l}\text { RBV. Knowledge absorption. } \\
\text { Learning in the organizations } \\
\text { boosts the entrepreneurs- } \\
\text { hip and the capabilities of } \\
\text { innovation. }\end{array}$ \\
\hline $\begin{array}{l}\text { Stevenson and Jarillo (1990); Zahra (1991; } \\
\text { 1993); Wiklund and Shepherd (2003, 2005); } \\
\text { Cardona (2010) }\end{array}$ & Internal factors & RBV. Financing capabilities. \\
\hline $\begin{array}{l}\text { Miles et al. (2006); Capelleras and Kantis } \\
\text { (2009); Gulati, (1998); Martins et al. (2015) }\end{array}$ & Internal Factors & $\begin{array}{l}\text { RBV. Internal and external } \\
\text { work cooperative networks. }\end{array}$ \\
\hline
\end{tabular}

Source: Own elaboration.

Different connotations of the EO and CE constructs, such as attitude, entrepreneurial mentality, entrepreneurial spirit among others, are not only considered difficulties when doing the work but also a challenge which are all related to the processes which lead to understand $\mathrm{CE}$ more easily and to analyze EO and CE both individually and in interrelation.

To determine the difference in meaning of $\mathrm{EO}$ and $\mathrm{CE}$, we will present a definition and meanings of both constructs provided by different authors. 


\subsection{Entrepreneurial orientation and corporate entrepreneurship, and their meanings}

When reviewing the literature, we found the EO and CE studies separately. Regarding their impact on entrepreneurial performance, there are authors such as Zahra (1993), Lumpkin and Dess (1996), Antoncic and Hisrich (2001), and Urbano et al. (2010).

Covin and Lumpkin (2011) questioned if the EO means disposition or actions, which paves the way to study this separatedly from the CE. Bouchard and Basso (2011) stated that the relationship has not been explored sufficiently and presented a theoretical proposition between EO and intrapreneurship that attempts to be contrasted statistically, generating questions with no answers yet. The last authors argued that both conceptual aproaches have been parallelly developed with little or not connection and that the vast gap among them is due to the delay in their convergence.

Corbett et al. (2013), in their analysis of the state of art and future research agenda, stated that conceptualizations about the domain of $\mathrm{CE}$ studies have turned the last years in two correlated phenomena of parallel theoretical development: CE and EO.

However, due to the intepretation of similarity of both phenomena by different previous studies or by the novelty of Bouchard and Basso's (2011) propositions, there has been little quantitative research. Hasan et al. (2013) statistically validated the EO relationship and the results of CE focused on innovative actions. Gelderen, et al. (2015) analyzed the relationship between the EO as intentions and actions in relation to the venture creation as another view on entrepreneurship of wide interest.

This work analyzes the meaning of the construct by referring to EO as the entrepreneurial attitude and spirit of looking for new business opportunities. This work is based on studies by Mintzberg (1994) and Miller (1983), which were subsequently denominated entrepreneurial posture by Covin and Slevin (1991) and then EO by Lumpkin and Dess (1996).

\subsubsection{The entrepreneurial orientation as attitude and willingness}

Entrepreneurial orientation is constituted as an attitude, fundamental antecedent to achieve the entrepreneurship of the firms, and manifested in the entrepreneurial spirit of its founders and employees. Covin and Lumpkin (2011) warned about the great weight given to the construct and its different labels. Additionally, they quote this definition of "orientation" given by the online Merriam - Webster dictionary (MW.com) "a usually general or lasting direction of thought, inclination, or interest" Covin and Lumpkin (2011, p.857).

In addition, posture as synonym of attitude is frequently used by different authors (Covin and Slevin, 1991; Covin and Lumpkin, 2011); in Merriam - Webster dictionary (2015), one of the definitions of posture runs like this "the attitude that a person or a group has toward a subject".

Besides, Dess and Lumpkin (2005) point out that the entrepreneurial posture is the central element of the entrepreneurial processes when those are integrated with environmental factors and other organizational and individual attributes. Covin and Slevin (1991) also explain that the EO as the likelihood of high direction to the change, the innovation, risk-taking, and compete roughly to achieve competitive advantages, and they considered those as an entrepreneurial strategy posture. These concepts allow broaden perspectives 
and differentiate between will and behavior or expressed in another way, between the entrepreneurial intention and the entrepreneurial action.

There are some different definitions for the EO that vary in the level of abstraction, intention and extension (Covin and Wales, 2011); Lumpkin and Dess (1996, p.137) establish one of the most recognized:

EO refers to the processes, practices, and decision-making activities that lead to new entry, as characterized by one, or more of the following dimensions: a propensity to act autonomously, a willingness to innovate and take-risks, and a tendency to be aggressive toward competitors and proactive relative to marketplace opportunities.

Thus, taking into account this definition, there is implicit the concept of willingness that can be correlated to intention, as well.

Theoretical joint developments of psychology and management allow to deep inside the relationships beetween intention, volition and actions at explaining how motivational tendencies, wishes, expectances, and subjective values determine the commintment to the action, reflected on a strong intention or goal to reach objectives (Kuhl 1985, Bratman 1987; Mitchell and al. 2007). So, entrepreneurial intention has been considered as a previous and determinat aspect in both the renewal processes and the performance of the entrepreneurial behaviors (Mitchell et al. 2007).

The Worldwide Bank (2015b, p.1) in the report "Mind, society and behavior" warns about the actions on political economy and entrepreneurial strategy: " interventions should bear in mind psychological and social specific factors that guide decision-making in a specific environment", and state that it can contribute to diminish such gaps between the intentions and the actions".

\subsubsection{The corporate entrepreneurship as actions}

During the literature review on the $\mathrm{CE}$, it is observed that the phenomenon has been widely studied for some couple of years now (Zahra 1991, 1993; Jin et al. 2005); Sharma and Chrisman (1999,p.13) define this concept as follows "the process in which an individual or group of individuals altogether build, renew and innovate a new organization".

Traditionally, the CE has been quietly related to actions (Burgelman 1983; Zahra 1991, 1993; Antoncic and Hisrich 2001; Jin et al. 2005), connected with the Theory of Destructive Action (Schumpeter 1942), by being referred to action, development in new products or improvement of the current ones, of processes and technologies or entering the new markets. For example, Kuratko et al. (2001) emphasize that entrepreneurial actions are the channels whereby entrepreneurship is held in some organizations.

In the same way, to clear up the difference between EO and CE meanings, Covin and Lumpkin (2011, p.858) establish that "in every single firm , it can be seen different features such as structure or culture to undertake, but it does not mean that those are to be effective". This affirmation is founded on an individual, with an entrepreneurial psychological profile, who does not necessarily become one, and was identified previously by Covin and Slevin (1991) pointing out that entrepreneurs are recognized due to their actions and by giving strong elements coming up with the idea that there may exist differences between both, entrepreneurial and behavioral attitudes. 
GEM Spain (2014, p.125) states that "the entrepreneurial spirit is the capability of the person to turn ideas into acts". Similarly, OCDE (2012), correlates the entrepreneurship to the entrepreneurial activities, which is understood as actions related to the identification and exploitation of new products, processes or markets.

McFadzean et al. (2005) give evidence of three key factors which can explain the dynamic and relationships between $\mathrm{CE}$ and innovation: entrepreneurial attitudes, vision, and entrepreneurial actions. Current studies try to determine the impact of EO with explained variables, using the construct "innovative performance" (Goodale et al. 2011; Hasan et al. 2013), related to innovation stated by Schumpeter (1942), which remain in the definition of innovation pointed by OCDE - Oslo (2005).

\subsection{Entrepreneurial orientation and corporate entrepreneurship and their direct and indirect relationships}

When analyzing the EO, CE and their relationships, it allows us to explain how the entrepreneurial attitudes are canalized through intentions and willingness and the latter ones in actions; with predisposition to undertake by means of strategies, resources and capabilities to obtain behaviors that boost the business renewal and innovation (Ireland et al. 2009; Moreno and Casillas 2008; Covin and Lumpkin 2011; Wales et al. 2011).

Ajzen (1991) developed the Theory Planned Behaviour (TPB), by trying to understand how social values influence attitudes and the latter ones influence intentions and behaviors. Theories of management, among other disciplines have broadly used TBP by going deeper in diverse applications that explain the transition of the intention to the action.

According to this approach, to provide intentions is not only to have predisposition and willingness to reach goals, but also to take into account sequential processes which allow to canalize the intentions, planning resources and capabilities, trying to direct organizational actions towards the final objectives. But, there are still some subjective elements that are difficult to establish, estimate and control (Bratman 1987; Velez 2012).

In the development from psychological theory, Dornyei (2000, p.521) stated: "a central feature of Action Control Theory is the separation of the 'predecisional phase' associated with the intention-formation process and the 'postdecisional phase' associated with the action implementation process within the motivated behavioural sequence".

In this way, from all previous considerations, we can establish the hypotheses as follows:

Hypothesis 1: The EO has a direct and positive effect on the CE.

\subsection{Capability of assessment and management of projects and the mediating effects between the $\mathrm{EO}$ and the $\mathrm{CE}$}

The EO focuses on remaining alert to the alterations presented in the environment by interpreting the effects for firms and looking for business opportunities (Covin and Slevin 1991; Covin and Lumpkin 2011). Thus, to take advantage of those, an organization should have currently heterogeneous resources and fulfill with features at being limited and difficult to imitate (Barney 1991). Some capabilities have been analyzed as antecedents from the CE founded in the RBV Theory. 
Miller (2011) poses questions about the factors that boost EO and the processes that are followed to implement new initiatives and which are the special capabilities that encourage a strong CE. This work attempts to answer partially the author's doubts and focuses on routines related to the projects, in which the phenomenon are manifested, which has reached a vast development as a field specialization management from both theory and enterprise practice.

According to literature reviewed of $\mathrm{CE}$, the capability to assess and manage projects has been little explored and has not been contrasted statistically, despite of being highly developed by management disciplinary fields such as the market, projects, finances among others.

The importance of the capability to formulate, assess and manage projects as a determinant of CE lies on the direct relationship with the entrepreneurial processes identified in the Theory Planned Behaviour (Bratman 1987; Velez 2012), which are integrated with the strategic planning and project management (Rosillo 2008 ; Arboleda 2013). Currently, literature presents on the one hand, the formulation and assessment of projects (Rosillo 2008; Sapag et al. 2014) and, on the other hand, project management (Project Management Institute 2008; Gido and Clements 2012;), when in fact those are two integrated processes.

Moreover, it is quite crucial for the organizations to identify ideas, know how to obtain, assess and make investment decisions to be used in the best ways by facing to a wide range of options, with the constraint of scarce financial resources that every single enterprise has (Cardona 2012; Sapag et al. 2014).

In this way, preparation, assessment and project management require of a series of capabilities, knowledge, and techniques; also, different studies are integrated in the analysis and the management is always present: marketing, engineering, legal, economic, environmental, administrative and financial (Méndez 2012; Arboleda 2013). For this reason, there are certain interdisciplinary, cohesive and coordinated which are expected collaborative work teams (Soriano and Urbano 2008, GEM España 2014).

Corbett et al. (2013), discuss topics of future agendas to be studied about the CE different internal processes, as antecedents of the phenomenon which are to be studied. These authors highlight the project management, resource allocation and business portfolio to be dealt by researchers.

The different dimensions of the EO established by Covin and Slevin (1991) indicated in Section 2.1.1., have influence in the development of the capability of assessment and management of projects, according to the degree of specialization of knowledge management and experience of the members that make up the company. For example, the propensity of senior management to act proactively and for change and innovation, boost the exploration of opportunities from the environment, and stimulate the formulation and evaluation of projects, that will be implemented with the resources and capabilities available or for developing (Sapag et al. 2014).

The willingness to take risks is given to making the decision to invest scarce resources in choosing the best projects to be implemented among many possible; those must be aligned with strategic and value creation of the company aims to increase sustainable competitive advantages. The assessment of projects provides the analysis of the results expected under conditions of uncertainty, which is trying to anticipate and estimate, using regression techniques and sensitivity analysis and scenarios; subsequently may be established different action plans for each of them (Brealey et al. 2006; Cardona 2012). 
In addition, the autonomy that employees and the willingness of the company to implement proactive ideas, impact the competitive aggressiveness and posture of entrepreneurial strategy, which should be analyzed foreseeing reactions competition, and performing a constant ex post evaluation: In project management, monitoring the results achieved over time it is included. These processes involve the adjustment of strategies to achieve pre-set goals and learning in the formulation, evaluation and project management.

From EO relationships with this capability, we proposed the following hypothesis:

Hypothesis 2: The EO has a direct and positive effect on the structuration of the capability to assess and manage projects.

If stages required to manage projects are considered from the idea until its implementation, we might observe that this is a process that includes preparation, assessment, implementation and operation, those processes follow a suitable management, since the routines included should be considered like an integrated capability (Arboleda 2013; Méndez 2012).

In a firm, this capability contributes to reach the long term strategic objectives portrayed in a development and financial plan. The investment decisions involved in the projects should be targeted to the firm value creation and be analyzed under cash flow techniques (Brealey et al. 2006; Cardona 2010, 2012).

These routines allow any organization to analyze the value creation and coordinate, by rationalizing the projects implemented and hierarchical, so that they cannot be done at any cost and the CE can be effective (Brealey et al. 2006; Cardona 2012). Thus, from the relation between this capability and the $\mathrm{CE}$, the following hypothesis is formulated:

Hypothesis 3: Structuration of the capability of assessment and project management have a positive and direct impact on the CE.

Current works start recognizing this capability as part of administrative processes and challenge for future research to be considered as mediator in the entrepreneurial processes (Goodale et al. 2011; Corbett et al. 2013; Lechner and Gudmundsson 2014). GEM Spain (2014, p.125) state the importance of this competence for entrepreneurship, pointing out links of "creativity, innovation and risk taking with the ability to plan and manage projects in order to achieve objectives".

In order that the EO be able to be reflected on the effective CE, it is mandatory an adequate selection, formulation and project management so that they have the opportunity to be built up successfully. It means to achieve the expected goals on the implementation stage, by fulfilling with both the investment budget and the objectives of every single project and its contributions to growth, firm profitability and add value.

When are considered the three direct and positive relationships: between EO and CE, between EO and the capability to assess and manage projects, and between the latter and the $\mathrm{CE}$, it can be expected that this capability act as a mediator factor in the relationship between the EO and CE. From the above approaches, you can set the following hypothesis:

Hypothesis 4: The relationship between EO and CE can be enhanced with a positive indirect effect through the mediator Capability of Assessing and Managing Projects construct. 
Figure 1

EO, capability of assessing and managing projects and impacts on the CE

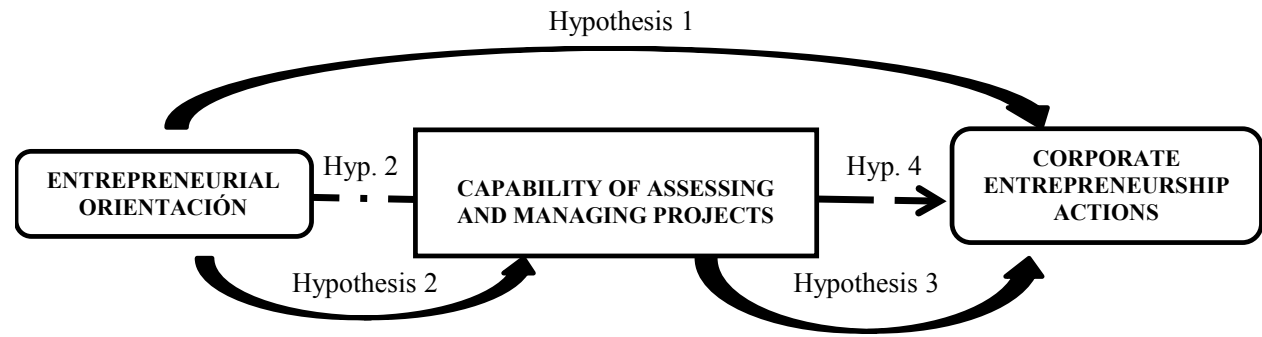

Source: Own elaboration.

Figure 1 shows the model integrated in a direct relation between the EO and CE and the relationships between the two constructs mediated by the capability of assessing and managing projects.

\section{METHODOLOGY}

The theoretical approach from the proposal and contrast of the formulated hypotheses is carried out by using structural equation modeling (SEM). In this way, in order to do the analysis of the EO in the SME, we bear in mind five proposed dimensions by Lumpkin and Dess (1996), which are jointly analyzed to be validated in the Latin American context.

\subsection{Data Collection and structuration of data base.}

We structured a data base with 543 SME obtained from The Chamber of Commerce of Medellin, from which 137 accepted to answer the survey, equivalent to $25.23 \%$ and representing a good response rate. This study was carried out by the sake of convenience due to the fact that the participation by the individuals included was voluntary and not chosen randomly.

The firms analyzed are located in the metropolitan area of Medellin, capital of Antioquia second region in participation in the GDP of Colombia (National Administrative Department of Statistic-DANE, 2005.) Medellin is known by its entrepreneurial spirit, industrial traditions and also because is the headquarters of important national and foreign entrepreneurial groups.

The database is the result of information obtained through fieldwork done between April 2013 and June 2014 and it was used to the estimation of the statistical proposed models.

In this manner, in Table 2 may be seen the classification of the SME according to the surveys derived from information obtained and organized for economic sector and the number of employees. 
Table 2

SME analyzed by economic sector and number of employees

\begin{tabular}{|c|c|c|c|}
\hline \multicolumn{4}{|c|}{ SME analyzed by number of employees and manufacturing subsector } \\
\hline \multicolumn{2}{|c|}{ Given by the number of employees } & \multicolumn{2}{|c|}{ manufacturing subsector } \\
\hline \multirow{4}{*}{ Small( less than 50) } & \multirow{4}{*}{$47,45 \%$} & Electricity & $2,92 \%$ \\
\hline & & Food & $11,68 \%$ \\
\hline & & Dressmaking & $21,90 \%$ \\
\hline & & Metallurgial industry & $18,98 \%$ \\
\hline \multirow{3}{*}{ Medium (More than 50 ) } & \multirow{3}{*}{$52,55 \%$} & Footwear & $4,38 \%$ \\
\hline & & chemicals & $20,44 \%$ \\
\hline & & Lithography & $9,49 \%$ \\
\hline \multicolumn{2}{|l|}{ Total } & \multicolumn{2}{|c|}{$100,00 \%$} \\
\hline
\end{tabular}

Source: Own elaboration.

To ensure the absence of bias in the data, we have evaluated the bias of non-response (a sample of 137 firms which did not accept to respond the questionnaire, has been compared with reference to the age and number of employees). The result revealed no significant differences between the two groups.

Equally important, we applied techniques to control the common method biases. Namely, we established two steps indicated by Podsakoff et al. (2003): First, we were very concise at doing the survey by saying participants that we that would protect anonymity in the responses, which helps to reduce in a way the subjectivity in which surveyed people answered.

Second, under the assumption that a high proportion of the variance of the common method is found, we could carry out a factorial and exploratory analysis of all variables which were analyzed as if they integrated a very single construct following the process indicated by Podsakoff et al. (2003) and Meade et al. (2007), and we verified that that there would not be any factors that explained the major proportions of the variance.

\subsection{Variables}

The questionnaire was structured with answers to the questions in Likert Scale. The survey was divided into three principal factors: EO and its five dimensions which comprising 26 questions; CE actions with 8 questions; finally, the related routines to the assessment and project management which included 8 questions.

To analyze the EO phenomenon in the studied firms, we used fundamented scales in the theoretical dimensions given by Covin and Slevin (1991), complemented by Lumpkin and Dess (1996) and used by the Center of Investigation and Sociologial studies of the University of Navarra, in its study to tecnological industrial enterprises in Spain. The variables were then adapted to the Colombian context and considered the dimension of innovation such as willingness and propensity. 
For the CE, were used scales proposed by Zahra (1993) and Jin et al. (2005), focused on concrete actions targeted to the development of new products, businesses, markets, operational and administrative processes and the internationalization. Current works use the CE factor with widespread innovative actions using variables that integrate the construct Innovative Performance (McFadzean et al. 2005; Goodale et al. 2011; Hasan et al. 2013).

Finally, for all internal processes related to the assessment and project management, we used scales of the works developed by Cardona $(2010,2012)$ including the training in assessment and project management, employee or area with responsibilities of assessment and project consolidations, determining the budget capital and financial evaluation of investment decisions. Such variables used in the model are shown in the Appendix.

\subsection{Model}

We established the EO, CE and the capability of assessing and managing projects (CAMPRO) as the three factors in which exploratory factorial analysis is done and also was verified the validity in the approach of the model; two phenomena studied at the same time EO and CE, which are analyzed in a relationship quantitatively little contrasted in previous studies, as already it justified. In this work these two factors are mediated by CAMPRO.

Firstly, exploratory factor analysis (EFA) was made, estimating the matrix of correlations of the variables and obtaining the factors, retaining those with a proper value higher than 1 and finding the corresponding results to the representation under a varimax orthogonal rotation proposed by Kaiser (1958), which allows to break down the total between the total variance and the different factors, and identifying which variables integrate each factor.

The EFA allows to identify the three factors EO, CE and CAMPRO associated in this work, which at the same time are related to every single dimension which makes part of it. The confirmatory factor analysis (CFA) is calculated by means of structural equations by relating the relationships found for the corresponding factors to verify the validity of the models proposed for each factor.

Afterwards, the direct and mediated effects of the variables observed and latent were interpreted, and carried out the adequate proofs of goodness of fit. Then, the hypotheses were validated throughout SEM and software Stata 13. The estimations were done taking into consideration the high likelihood method, which according to Perez (2008), neither biased, efficient nor invariable to any type of scales, but highly recommended when the sample sizes are between 100 and 200 observations.

\section{RESULTS}

\subsection{Exploratory factor analysis}

The exploratory analysis requires the previous Harman's test application whose principal assumption is that if a substantial amount of the variance of the common method, there will be just one factor coming from the factor analysis with the highest amount of the variance focused on this (Podsakoff et al. 2003; Meade et al. 2007). The first component 
explains the $30.38 \%$ of the variance and following the Kaiser's criteria (1958), we can keep seven factors which explain the $76.45 \%$ of the variance.

\subsubsection{Entrepreneurial orientation}

For the EO, the statistics KMO 0.46, alpha -Cronbach 0.799 and the Bartlett's sphericity test $(\mathrm{p}<0.01)$, it was recommend to use an exploratory analysis which was previously done by obtaining five dimensions that explained a $94.53 \%$ of the total variance, which were classified as follows: Assumption of risk, proactivity, tendency to innovate, autonomy and competitive rivalry.

The Alpha Cronbach is higher than 0.6 in all dimensions, except for Competitive Rivalry which was about 0.481 . However, as the alpha Cronbach was 0.799 for the EO factor, due to the importance of such a relationship, we took it into consideration at the time of specifying the model. The statistical values can be viewed in Table 3 .

Table 3

Statistical proof dimensions of entrepreneurial orientation

\begin{tabular}{|c|c|c|}
\hline Bartlett Test & P-value $<0.001$ & \\
\hline & Alpha Cronbach & Kaiser-Meyer-Olkin \\
\hline Global Model & 0.8768 & 0.767 \\
\hline ENTREPRENEURIAL ORIENTATION & 0.799 & 0.746 \\
Autonomy & 0.732 & 0.783 \\
\hline Risk taking & 0.768 & 0.691 \\
\hline Proactivity & 0.736 & 0.730 \\
\hline Willingness to innovate & 0.639 & 0.642 \\
\hline Competitive rivalry & 0.481 & 0.508 \\
\hline
\end{tabular}

Source: Own elaboration.

The EFA is conscious about the EO by showing the validity of the findings in the dimensions that integrate the construct. Thus, the dimensions established by Lumpkin and Dess (1996) and already contrasted in previous works (Wiklund and Shepherd 2005; Moreno and Casillas 2008; Hasan et al. 2013; Martins and Rialp 2013; Martins et al. 2015).

The results of the estimates of the CFA using SEM also show that the effect between the EO and its five dimensions are positive and significant in all the cases, with a $p<0.001$ : autonomy (standardized coefficient 0.6209), assumption of risk (standardized coefficient 0.5502 ), proactivity (standardized coefficient 0.7374 ), willingness to innovate (standardized coefficient 0.5401 ) and competitive rivalry (standardized coefficient 0.4920 ). 


\subsubsection{Corporate entrepreneurship as actions}

For this factor, considered the CE actions, the statistics KMO of 0.58, alpha Combrach 0.671, and Bartlett's sphericity test, allow the exploratory analysis. Thus, with the considered variables, the results show one factor that explain the $74.65 \%$ of the total variance which contains six variables.

The findings are coherent with Zahra (1993) and Jin et al. (2005) who show scales to measure the results in which the $\mathrm{CE}$ is related to entrepreneurial actions. In this work, authors point out the positive relationship between the $\mathrm{CE}$ with the entrepreneurial performance. Similar results were found by Hasan et al. (2013), due to the fact that there are positive relationships about the $\mathrm{CE}$ with the innovation results, measured by the construct Innovative Performance.

\subsubsection{Capability to assess and manage projects}

For this factor, the statistics KMO 0.895 and the Bartlett's sphericity test $(\mathrm{p}<0.01)$ are to carry out an exploratory analysis. As a result of this exploratory analysis comes out an only factor that explains a $100 \%$ of the total variance and a consequently denominated capability to assess and manage projects - CAMPRO. The alpha Cronbach is 0.8666 for this factor.

After the validity under the CFA, we establish a definition of the capability to assess and manage projects, proposed as a theoretical construct for consideration by academics and practitioners as follows:

In the corporate entrepreneurship interrelated processes are developed which come from the brainstorming of an idea until its startup by including projects formulation, feasibility analysis, implementation decisions and the corresponding investments. Such processes are managed, controlled and interrelated with generic leadership competences, communication, teamwork among others, which boost roughly entrepreneurial strategies in the organizations (developed by authors).

\subsection{Structural Equation Models (SEM)}

Departing from the validity of CFA for the EO factors, CE actions and CAMPRO, the hypotheses proposed in two models were contrasted; the decision to estimate two models which corresponds to the interest of studying separately the direct effects that EO has over the $\mathrm{CE}$ actions, and the indirect one mediated by CAMPRO. In other words, the first model gives estimates for hypothesis 1 (Figure 2).

Two current works analyze statistically the relationship intention-action. The first one, contrasts the EO as intention and results innovation of CE as actions (Hasan et al. 2013). The second one, validates the EO relationship as the intention and actions under the view of venture creation (Gelderen et al.2015). Consequently, the results of this study are coherent with Hasan et al. (2013) at validating that the EO as the intention and willingness have positive and direct effects over the CE actions.

On the other hand, the second model allows to estimate hypotheses 2, 3 and 4 (see Figure 3). In addition, we take into account the likely effect that the size of the firm has because 
of the number of employees. So, over the factors studied, we attempted to give control by dividing the samples between those firms that have less than 50 employees and those that had 50 or more (Table A.2 and Table A.3). The relationships between the factors that are analyzed in the second model can be clearly observed in Figure 3 and Table 4.

Figure 2

\section{Entrepreneurial Orientation and the impacts on $\mathrm{CE}$}

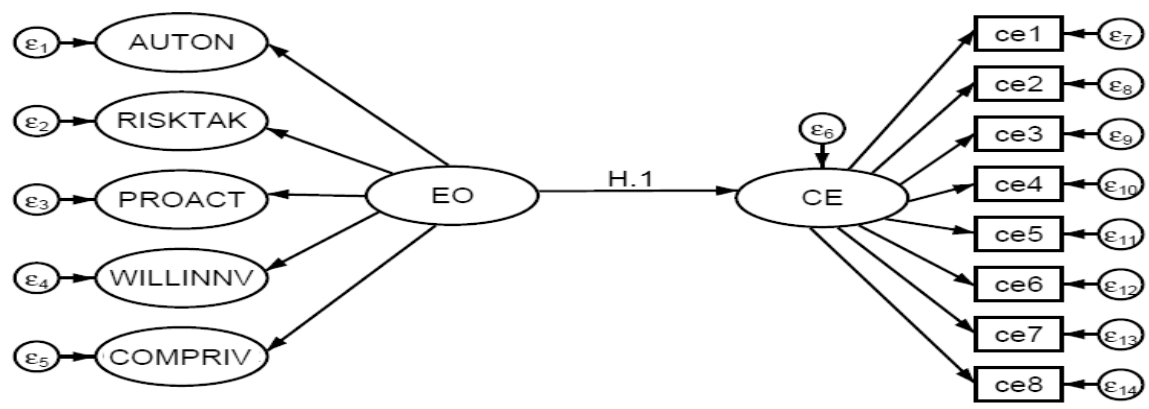

Source: Own elaboration.

Figure 3

Model: EO, Capability to assess and manage projects and impact over CE actions

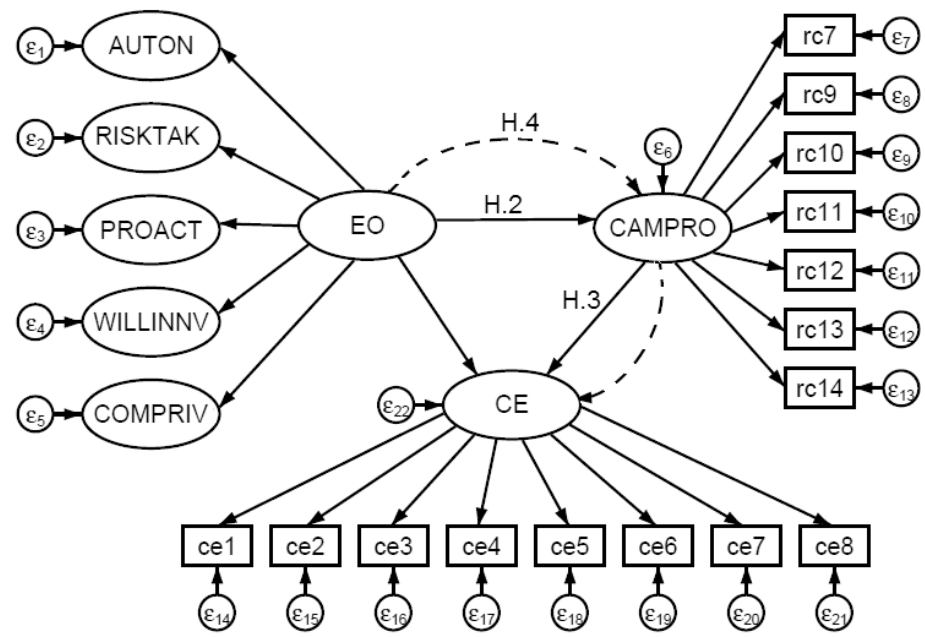

Source: Own elaboration. 
Now, in Table 4, we show the results for the estimation of the models; the first one, in relation to hypothesis 1 , and the second one, related to hypotheses 2,3 and 4 .

Table 4

Estimation Results for the hypotheses in both models

\begin{tabular}{|l|c|c|}
\hline \multicolumn{1}{|c|}{ Hypothesis } & Firms<50 & Firms $\mathbf{5 0 0}$ \\
\cline { 1 - 1 } $\begin{array}{l}\text { MODEL 1 } \\
\text { H 1: Entrepreneurial Orientation à corporate entrepreneu- } \\
\text { rial actions }\end{array}$ & 0.257 & $0.464 * * *$ \\
MODEL 2 & & $0.712^{* * *}$ \\
$\begin{array}{l}\text { H 2: Entreprenerurial Orientation à capability to assess and } \\
\text { manage projects }\end{array}$ & $0.657^{* * *}$ & $0.456^{* * *}$ \\
$\begin{array}{l}\text { H 3: Capability to assess and manage projects à corporate } \\
\text { entrepreneurial actions }\end{array}$ & $0.286^{*}$ & $0.368^{* * *}$ \\
\hline $\begin{array}{l}\text { H 4: Entrepreneurial Orientation à Capability to assess and } \\
\text { manage projects à Corporate entrepreneurial actions }\end{array}$ & 0.201 & \\
\hline
\end{tabular}

Notes: $* * *: 99 \%$ confidence interval. $* 90 \%$ confidence interval.

Source: Own elaboration.

Regarding Table 4, we can draw the following conclusions. First, about hypothesis 1 , it is proved that the EO has a positive relationship over the CE which is statistically significant for the firms with more than 50 employees. Moreover, the second hypothesis assures to find an EO positive and direct effect over the CAMPRO structuration, and turns out to be statistically important for the two enterprises groups studied. Third, according to the hypothesis three, the structuration of the capability to assess and manage projects has a significant and positive impact over the CE, for both firms groups studied.

Finally, hypothesis four, which contrasts the positive relationship between the EO and the CE mediated by CAMPRO turns out to be statistically significant just for those enterprises with more than 50 employees. In the latter hypothesis, we can prove all by considering CAMPRO as a mediating variable between the $\mathrm{EO}$ and the $\mathrm{CE}$ after verifying the conditions established by Baron and Kenny (1986). The significance of this hypothesis is less than that observed in the direct relationship of EO and CE validated by hypothesis 1 , and has a partial effect of mediating relationship.

Lastly, we took into consideration four goodness of fit tests for models 1 and 2 which are presented ahead by showing between parenthesis the results of the second model estimated: the Chi-2 adjusted ( Chi-2/ degrees of freedom) which obtained a value of 1.717 (1.701) that at being lower than 3.0, can be interpreted as a good model adjustment ; RMSEA $0.093(0.096)$, found in the suitable range, close to 0.08 ; the coefficient of determination $0.843(0.872)$, which resembles $\mathrm{R}^{2}$ for regression models and indicates a good adjustment when approaching. 


\section{DISCUSSION, CONCLUSIONS AND IMPLICATIONS}

\subsection{Discussion and limitations}

Based on previous studies of the dimensions that integrate the EO (Covin and Slevin 1991; Lumpkin and Dess 1996), and the RBV Theory (Barney 1991), this research attempted to clarify the difference and the complementarity between the EO seen as willingness and intention and the $\mathrm{CE}$ as behavior and actions, two constructs that have been frequently used indifferently. Besides, the hypothesis about a positive relationships between the EO and CE was validated according to the results of the standardized coefficient (0.675) and one high significance $(\mathrm{p}<0.1)$.

We could conclude that in the SME, the EO can be driven to the highest efficiency actions of CE, which allowed somehow to answer question in this regard of Miller (2011), Covin and Lumpkin (2011) and to validate the theoretical propositions established by Bouchard and Basso (2011). This result is also coherent with the positive relationship between EO and innovation performance validated by Hasan et al. (2013), an only baseline study found.

It is necessary that the SME structure capabilities, some already studied in relation to the EO and CE phenomena and other which have not been studied yet. After 30 years of studying strategies and EO, Miller (2011) still poses doubts about which capabilities are the ones with the highest impacts on the CE. In this way, we are to contrast in this study the capability to assess and manage projects with the two phenomena analyzed.

Departing from the RBV Theory and after being validated through confirmatory factor analysis, we can to offer a new theoretical construct defined as Capability to assess and manage projects; further it was confirmed the direct and positive relationship between the EO and this capability with SEM. The importance of this finding lies on the foundations so the entrepreneurial intentions can be driven to the implementation of initiatives, which have been identified, formulated, evaluated, managed in a adequately way, in order to create sustainable competitive advantages and add value to the company.

For such firms whose employees are more than 50 in number, the positive relationships resulted statistically significant between the structuration of the capability of assessing and managing projects and the $\mathrm{CE}$. The same happened with the relationship between the EO and its direct effect on the CE, which was mediated by such capability, but was not significant in those enterprises with less than 50 employees. The descriptive statistic results show for this type of firms analyzed that they have not widely developed this capability and present weakness in the processes that make up it.

For instance, it was found that there is not a good training in projects for employees of SME, since was observed weaknesses in the professionals who performed the relative functions to the capability to assess and manage projects, use cash flow methodologies, decision-making criteria of investment used, and the tracking and controlling of the projects implemented. Furthermore, there are other weaknesses regarding methodologies for prioritizing between multiple resulting projects of a higher $\mathrm{EO}$ and $\mathrm{CE}$ effective processes.

Despite of the growing interest on the specialization projects in the management areas both in theory and in the enterprise practice, the literature review shows that little has been linked this capability with the phenomenon studied. Moreover, the study has been frag- 
mented, focused and split out into two great processes. On the one hand, the formulation and assessment of projects; on the other hand, their direction, which have recently begun to integrate.

In turn, the methodological contribution of this study comes from the structural analysis of different determinant variables of the EO and its relationship with the CE, mediated by the capability of assessing and managing projects, with which we can obtain a more integrated image of the entrepreneurial phenomenon.

This study advances our understanding of the complex EO-CE relationship, however, it should be emphasized that this research has some limitations. First of all, it is difficult to differentiate between $\mathrm{EO}$ and the $\mathrm{CE}$ giving different names for attitude, entrepreneurial mindset, entrepreneurial posture, but at the same time, was a challenge for this research to organize and systematize different approaches about the concepts and their relationships, achieving the best understanding in both phenomena which are integrated in the processes leading to concrete entrepreneurial actions.

Also was a little bit of complex in the fieldwork to make appointments for visiting the firms which accepted to participate and answer the questionnaire, common in this type of study for collecting information from primary sources, in order to structure the database. Finally, we could obtain a convenient sampling system, rather than a probabilistic and random one, by being the latter one, that one which allowed higher confidence levels in the statistical studies and inferences to the total population of the SME in the region analyzed.

Additionally, the data collection for the formulation of the constructs has been done in one period only, which characterizes the analysis as transversal.

\subsection{Conclusions and implications}

Due to the CE importance in the revitalization of the firms and in the innovation achievement and the competitive advantages, there is still an interest from decades in the understanding of those phenomena. In this way, it can be said that the results of the $\mathrm{CE}$ can be more effective when having the attitude denominated EO, and supported in formal processes of strategic planning, with structuration of capabilities heterogeneous, which are difficult to imitate.

The SME is characterized by the resource weaknesses available and the fragile organizational structures from where it lies the importance of developing, strengthen and grow in more solid, dynamic, steady organizations, which can be reached by working individually or in groups with other organizations and the Alliance University-Enterprise- Government.

This study deepens understanding of the EO and CE phenomena simultaneously by taking into account their differences, as well as their complementarity explained by the complexity characterized by the planning processes, when attitude, intention and the action interact with each other, leading to behaviors and results found deliberately. The results obtained in the current study allow to verify part of the theoretical relationships proposed by showing the positive direct effects between the EO and CE, and the effects between the indirect ones between the constructs, mediated by the capability of assessing and managing projects at being of an important competence in the entrepreneurial processes, that meets the criteria of RBV Theory (Barney 1991). 
From the practical point of view and the results of the research, the phenomena EO and $\mathrm{CE}$ can be relevant due to the dynamism which the existing organizations generate regardless about the age, size and legal organizations. In this manner, it transcends beyond a different perspective of the entrepreneurial study, different of venture creation. The last one in which has been focused the public policies that promote and support entrepreneurship since the 21 th century for the Colombian case; after 2012 it is been redirected to the CE.

The firms should have as components of entrepreneurial strategy, strengthening the EO and its penetration to the whole organization, having a deep knowledge of the conditions of the external environment, clients' needs and competence, collaborative networking, knowledge absorption, among others (Covin and Wales 2011; Bouchard and Basso 2011; Wales et al. 2011).

In this way, the findings of this study and the models proposed will be important for all kinds of organizations. However those results may be considered more meaningful for SME due to their weaknesses and limitations in resources.

Additionally, at considering the analysis of the little impact of the Colombian public policies in CE and innovation, according to results reached by World Economic Forum (2014), could be taken into consideration by the State to consider adjustments in the regulations to support more effectively the real sectors and in particular the SME.

On the other hand, higher education institutions which train professionals in the administrative fields or in other similar disciplines could use the findings of the research to complement the designs of the curricula to form an entrepreneurial spirit of their learners and improve the entrepreneurial consultancy processes in which they participate.

To continue with the analysis of the $\mathrm{EO}$ and $\mathrm{CE}$ and contribute to a better understanding and interaction of those phenomena studied future lines of research could be directed to the joint analysis of their antecedents and impacts in the firm performance.

Also in the scope of this paper, the relationship between both phenomena and the ability to assess and manage projects was analyzed, future works could keep on the exploration of the other organizational capabilities, somehow already established from the theories, and some others still hidden or which have not been contrasted statistically yet. In this manner, other CE capabilities could be integrated in a multidimensional model and analyzed their mediating roles between the $\mathrm{EO}$ and the $\mathrm{CE}$.

Regard the transversal character of the analysis done, future research could endow this study with a longitudinal approach by gathering information for the design of constructs in different years, which might contribute someway dynamism to the analysis. When trying to measure the EO, capabilities and CE of the SME in different time periods, it might allow the gathering of more precise results of the transformations occurred in the organizations, and even in the change of perceptions.

\section{ACKNOWLEDGMENTS}

We especially acknowledge the Medellin Chamber of Commerce for providing the database of the SME of the region. Also, we regard to all executives of the firms that contributed vastly in this study, as well as the undergraduate EAFIT University Economy student, Sebastian Emilio Henao Bedoya, for his contribution to this research and, more importantly, the EAFIT University for financing this research project. 


\section{REFERENCES}

Ajzen, I., 1991. The Theory of Planned Behavior. Organizational Behavior and Human Decision Processes, 50(2), 179-211.

Álvarez,C. and Urbano, D., 2011. Environmental Factors and Entrepreneurial Activities in Latin America. Academy, Magazin of Administration, 48, 31-45.

Antoncic, B. and Hisrich, R., 2001. Intrapreneurship: Construct Refinement and CrossCultural Validation. Journal of Business Venturing, 16(5), 495-527.

Arboleda, V.G., 2013. Formulación de Proyectos. En Proyectos. Formulación, Evaluación y Control, $3^{\text {a }}$. ed. Cali: Alfaomega, 45-334.

Barney, J. B., 1991. Firm resources and sustained competitive advantage, Journal of Management, 17(1), 99-120.

Baron, R. M. and Kenny, D. A., 1986. The Moderator-Mediator Variable Distinction in Social Psychological Research: Conceptual, Strategic, and Statistical Considerations. Journal of Personality and Social Psychology, 51(6), 1173-1182.

Bratman, M. E., 1987. Intention, Plans, and Practical Reason. Cambridge, Massachusetts: Harvard University Press.

Brealey R., Myers S. and Allen F., 2006. Principios de Finanzas Corporativas. $7^{\mathrm{a}}$ ed. España: Mc. Graw Hill.

Bouchard, V. and Basso, O., 2011. Exploring the links between entrepreneurial orientation and intrapreneurship in SMEs. Journal of Small Business and firms Development, 18(2), 219-231.

Burgelman, R. A., 1983. Corporate Entrepreneurship and Strategic Management: Insights from a Process Study. Management Science, 29(12), 1349-1364.

Capelleras, J. L. and Kantis, H., 2009. El fenómeno del crecimiento de las nuevas empresas. En: Nuevas empresas en América Latina: factores que favorecen su rápido crecimiento. Barcelona: Universitat Autònoma de Barcelona, 1-18.

Cardona, R. A., 2010. Planificación financiera en las pyme exportadoras. Caso de Antioquia, Colombia. Administer 16, 50-74.

Cardona, R. A., Cardona, J. and Naranjo, A. P., 2012. Priorización de proyectos del sector Real. PODIUM, UESS, Ecuador, 21, 9-29.

Corbett, A., Covin, J. G., O'Connor, G. C. and Tucci, C. L., 2013. Corporate Entrepreneurship: State-of-the-Art Research and a Future Research Agenda. Journal of Product Innovation Management, 30(5), 812-820.

Covin, J.G. and Slevin, D. P., 1989. Strategic management of small firms in hostile and benign environments. Strategic Management Journal, 10(1), 75-87.

Covin, J.G. and Slevin, D, P., 1991. A Conceptual model of entrepreneurship as firm behavior. Entrepreneurship: Theory and Practice, 16, 7-25.

Covin, J., and Lumpkin, G.T, 2011. Entrepreneurial Orientation Theory and Research: Reflections on a Needed Construct. Entrepreneurship Theory and Practice, 35(5), 855872.

Covin, J. and Wales, W., 2011. The Measurement of Entrepreneurial Orientation. Entrepreneurship: Theory and Practice, 36(4), 1-26.

Departamento Administrativo Nacional de Estadística -DANE, 2005). Cuentas Nacionales Consolidadas del Censo 2005, http://www.dane.gov.co/ (16 de agosto de 2014). 
Dess, G. and Lumpkin, G., 2005. The Role of Entrepreneurial Orientation in Stimulating Effective Corporate Entrepreneurship. The Academy of Management Executive, 19(1), 146-157.

Dess, G., Lumpkin, G. and Jeffrey, E., 1999. Linking Corporate Entrepreneurship to Strategy, Structure and Process: Suggested Research Directions. Entrepreneurship Theory and Practice, 23, 85-102.

Dornyei, Z., 2000. Motivation in action: Towards a process-oriented conceptualisation of student motivation. British Journal of Educational Psychology, 70, 519-538.

Gelderen, M., Kautonen, T. and Fink, M., 2015. From entrepreneurial intentions to actions: Self-control and action-related doubt, fear, and aversion. Journal of Business Venturing, 30, 655-673.

Gido, J. and Clements, J. P, 2012. Administración exitosa de proyectos. México, CENGAGE Learning.

Global Entrepreneurship Monitor España (2014). Santander: Editorial de la Universidad de Cantabria.

Goodale, J. C., Kuratko, D. F., Hornsby, J. S. and Covin, J. G., 2011. Operations management and corporate entrepreneurship: The moderating effect of operations control on the antecedents of corporate entrepreneurial activity in relation to innovation performance. Journal of Operations Management, 29(2), 116-127.

Gulati, R, 1998. Alliances and network. Strategic Management Journal, 19, 293-317.

Hasan, K., Syyedhamzeh, N. and Ali, F., 2013. The influence of entrepreneurial orientation on innovative performance. Journal of Knowledge-based Innovation in China, 5(3), 262-278.

Ireland, R. D., Covin, Jeffrey, G. and Kuratko, D. F., 2009. Conceptualizing Corporate Entrepreneurship Strategy. Entrepreneurship Theory and Practice, 33(1), 19-47.

Jin, C., Zhaohui, Z. and Wang, A., 2005. A system model for corporate entrepreneurship International Journal of Manpower, 26(6), 529-543.

Kaiser, H.F, 1958. The varimax criterion for analytic rotation in factor analysis. Psychometrika, 23, 187-200.

Kuhl, J, 1985. Volitional mediators of cognition-behaviour consistency: Self-regulatory processes and action versus state orientation. En: J. Kuhl and J. Beckmann, ed., Action control: From cognition to behavior, New York: Springer, 101-128.

Kuratko, D. F, 2007. Corporate Entrepreneurship. Foundations and Trends in Entrepreneurship. 3(2), 151-203.

Kuratko, D. F. and Audretsch, D. B., 2009. Strategic Entrepreneurship: Exploring Perspectives an emerging Concept. Entrepreneurship Theory and Practice, 33(1), 1-17.

Kuratko, D. F., Ireland, R. D. and Hornsby, J. S., 2001. Improving firm performance through entrepreneurial actions: Acordia's corporate entrepreneurship strategy. Academy of Management Executive, 15(4), 60-71.

Kuratko, D. F., Hornsby, J. S. and Covin, J. G., 2014. Diagnosing a firm's internal environment for corporate entrepreneurship. Business Horizons, 57, 37- 47.

Lechner, C. and Gudmundsson, S., 2014. Entrepreneurial orientation, firm strategy and small firm Performance. International Small Business Journal, 32(1), 36-60.

Lumpkin, G.T. and Dess, G., 1996. Clarifying the entrepreneurial orientation construct and linking it to performance. Academy of Management Review, 21, 135-173. 
Lumpkin, G.T. and Dess, G., 2001. Linking two dimensions of Entrepreneurial Orientation to firm performance: the moderating role of Environment and Industry life cycle. Journal of Business Venturing, 16, 429-451

McFadzean, E., O'Loughlin, A. and Shaw, E., 2005. Corporate entrepreneurship and innovation part 2: a role and process based approach. European Journal of Innovation Management, 8(4), 393-408.

Martins, I., Uribe, F. and Mesa, D., 2012. Contribución de la orientación emprendedora a la rentabilidad de las pymes: un análisis contingente considerando la función del entorno. Revista ECOS de Economía, 35, 45-71.

Martins, I., and Rialp, A., 2013. Entrepreneurial orientation, environmental hostility and SME profitability: a contingency approach. Cuadernos de Gestión, 13(2), 67-88.

Martins, I., Rialp, A., Rialp, J., and Aliaga, I., 2015. El Uso de las Redes como Propulsor para la Orientación Emprendedora y el Crecimiento de la PYME. Innovar, 25(55), 117-130.

Meade, A. W., Watson, A. M., and Kroustalis, M., 2007. Assessing common methods bias in organizational research. In: 22th Annual Meeting of the Society for Industrial and Organizational Psychology Proceedings, Charlotte: North Carolina State University, $1-10$.

Méndez, R., 2012. Introducción a la gerencia de proyectos. In Formulación y Evaluación de Proyectos, 434-459, Bogotá: Incontec Internacional.

Miller, D, 1983. The correlates of entrepreneurship in three types of firms. Management Science, 29, 770-791.

Miller, D, 2011. Miller (1983). Revisited, A Reflection on EO Research and Some Suggestions for the Future. Entrepreneurship Theory and Practice, 35(5), 873-894.

Mintzberg, H., 1994. The Rise and Fall of Strategic Planning, Harvard Business Review, 60, 107-114.

Mitchell, R. K., Busenitz, B. B., Gaglio, C. M., McMullen, J. S., Morse, E. A. and Smith, J. B., 2007. Central Question in Entrepreneurial Cognitions Research. Entrepreneurship Theory and Practice, 31(1), 1-27.

Moreno, A. and Casillas, J., 2008. Entrepreneurial Orientation and Growth of SMEs: A Causal Model. Entrepreneurship Theory and Practice, 32(3), 507-528.

OECD- Scientific and Technological Consultative Forum, 2012.The OECD innovation strategy: getting a head start on tomorrow, 95-130, Paris: OECD.

Pérez, C, 2008. Econometría Avanzada: técnicas y aplicaciones. Madrid: Prentice Hall.

Podsakoff, P. M., MacKenzie, S. B., Lee, J. andPodsakoff, N., 2003. Common method biases in behavioral research: a critical review of the literature and recommended remedies. Journal of Applied Psychology, 88, 879-903.

Project Management Institute, 2008. A guide to the Projec Management Body of Knowledge (PMBOK Guide). Pennsylvania, PENN: PMI.

Rosillo, J, 2008. Introducción. In Formulación y Evaluación de Proyectos de Inversión para Empresas Manufactureras y de Servicios, $6^{\text {a }}$. ed. Bogotá: Cengage Learning, 13-35.

Sapag C. N., Sapag C. R., Sapag P. and Jose Manuel, 2014. El estudio de proyectos. En: Preparación y Evaluación de Proyectos, $8^{\mathrm{a}}$. ed. México: McGraw Hill, 1-12.

Schumpeter, J, 1942. Capitalism, Socialism and Democracy. New York (Ed.), Harper and Row Publishers. 
Sharma, P., and Chrisman, J, 1999. Toward a reconciliation of definitional issues in the field of corporate entrepreneurship. Entrepreneurship Theory and Practice, (31), 11-27

Soriano, D. R., and Urbano, D., 2008. Overview of Collaborative Entrepreneurship: An Integrated Aproach Between Business Decisions and Negociations. Group Decis Negot, 18(5), 419-430. DOI: 10.1001/s 10726-008 9134-x.

Stevenson, H., and Jarillo, J., 1990. A paradigm of entrepreneurship: Entrepreneurial Management. Strategic Management Journal, 11, 17-27.

Urbano, D., Toledano, N. and Soriano, D. R, 2010. Prácticas de gestión de recursos humanos y desarrollo de nuevos proyectos innovadores: Un estudio de casos en las PYME. Universia Business Review, 29,116-130.

Wales, W., Monsen, E. and McKelvie, A., 2011. The Organizational Pervasiveness of Entrepreneurial Orientation. Entrepreneurship Theory and Practice, 35(5), 895-922.

Wiklund, J. and Shepherd, D., 2003. Knowledge-Based Resources, Entrepreneurial Orientation, and the Performance of Small and Medium-Sized Businesses. Strategic Management Journal, 24, 1307-1314.

Wiklund, J. and Shepherd, D., 2005. Entrepreneurial orientation and small business performance: a configurational approach. Journal of Business Venturing, 20, 71-91.

Wiklund, J., Davidsson, P., Audretsch, D. B. and Karlsson, C., 2011. The Future of Entrepreneurship Research. Entrepreneurship Theory and Practice, 35, 1-9.

World Bank, 2015a. Doing Business 2015: Going Beyond Efficiency, Washington, DC: World Bank

World Bank, 2015b. World Development Report 2015 summary: Mind, Society and Behavior, General view. Washington DC: World Bank.

World Economic Forum -WEF. (2014). Theglobal competitiveness. Geneva: World Economic Forum.

Zahra, S. A., 1991. Predictors and financial outcomes of corporate entrepreneurship: an exploratory study. Journal of Business Venturing, 6, 259-286.

Zahra, S. A., 1993. Environment, corporate entrepreneurship and financial performance: a taxonomic approach. Journal of Business Venturing, 8, 319-340.

Zahra, S. and George, G., 2002. Absorptive capacity: A review, reconceptualization, and extension. Academy of Management Review, 27 (2), 185-203. 


\section{APPENDIX}

Table A.1

\section{Questionnaire and variables used in the model}

\begin{tabular}{|c|c|}
\hline & ENTREPRENEURIAL ORIENTATION \\
\hline & PROACTIVITY \\
\hline oe1 & The enterprise does not remain the traditional business model and looks for the innovative actions face to the market. \\
\hline oe2 & $\begin{array}{l}\text { We implement changes in the enterprises which affect the sector performance generally before the competence by being } \\
\text { reactive to contrarrestar revials' decisions. }\end{array}$ \\
\hline \multirow[t]{2}{*}{ oe3 } & Normally, the new products in the market have been developed by the enterprise introduced by other companies. \\
\hline & RISK-TAKING \\
\hline oe4 & Preferably, the enterprise develops risky and unknown business initiatives but that could be highly profitable. \\
\hline $0 e 5$ & $\begin{array}{l}\text { When facing decision-making in uncertain situtations, the enterprise opts for taking advantage of the opportunties and act } \\
\text { cautiously in order to avoid costly mistakes. }\end{array}$ \\
\hline \multirow[t]{2}{*}{$0 \mathrm{e6}$} & $\begin{array}{l}\text { Due to the changing environment, it is better to explore it cautiously and precariously instead of doing it gradually and } \\
\text { timidly. }\end{array}$ \\
\hline & INNOVATION WILLINGNESS \\
\hline oe7 & the enterprise has modified its organizational structures to increase the innovations. \\
\hline oe8 & $\begin{array}{l}\text { resources allocated for the company a I+Dincrease annually significantly in relation to the enterprise income growing and } \\
\text { the budget from this rubirc sector. }\end{array}$ \\
\hline oe9 & Innovation is disperse in the whole organization and is not centralized. \\
\hline $0 e 10$ & $\begin{array}{l}\text { The new products developed by the enterprises correspond to meaningful changes and not to ehancement of the current ones } \\
\text { in the market. }\end{array}$ \\
\hline oe11 & $\begin{array}{l}\text { The implementation of new technologies correspond to radical trasformations more than to existing enhancemnt } \\
\text { transformations. }\end{array}$ \\
\hline oe12 & New technologies have been developed by the enterprises and not acquired in the market. \\
\hline oe13 & the enterprise innovates permanently the administrative processes and in systems formation. \\
\hline \multirow[t]{2}{*}{ oe14 } & $\begin{array}{l}\text { the strategy of the company focuses morre on competing in differentiation (related to the attributes of the product, quality, } \\
\text { innovation, research and development and new market niches) rather than leadership in costs and low pricesque (improve } \\
\text { efficiency) }\end{array}$ \\
\hline & Envorimental Conditions and Commercial Rivalrv \\
\hline oe15 & $\begin{array}{l}\text { given to both external insecure and unstable environment in which the enterprises run constanlty changing the marketing } \\
\text { strategies }\end{array}$ \\
\hline oe16 & Rivals's actions are roughly difficult to predict. \\
\hline oe17 & Rivalry of the sector is very high and there exists a strong compettitive aggressiveness. \\
\hline oe18 & the rate in which products/ services become obsolete is high for this sector. \\
\hline oe19 & the damand and consumers' taste are strongly diffcult to foretell. \\
\hline \multirow[t]{2}{*}{ oe20 } & the techlogical development of the industry or sector is slightly high. \\
\hline & AUTONOMY \\
\hline oe21 & $\begin{array}{l}\text { The enterprise has incentives for the entrepreneurs employees which come up with new ideas, projects as benefits financial } \\
\text { compensations, awards, acknowledgments, promotional opportunities }\end{array}$ \\
\hline oe22 & In general, the entrepreneurial spirit level in employees of the organizations is considered to be high. \\
\hline oe23 & $\begin{array}{l}\text { we encourage individuals and groups to break dowm paradigms instead of keeping on with processes and standarized } \\
\text { decision strategies }\end{array}$ \\
\hline oe24 & $\begin{array}{l}\text { the internal realtionships of the company, the workplace in groups, communication and the cooperation, encourage } \\
\text { cooperative entepreneurship. }\end{array}$ \\
\hline oe25 & En la firma se tolera el fracaso, ante los cambios propuestos y resultados de las ideas implementadas por los empleados \\
\hline \multirow[t]{2}{*}{ oe26 } & The hierarchichally of the enterprises are flexible and adjusted to the entrepreneurial and iinovation needs. \\
\hline & CAPABILITY OF ASSESSING AND MANAGING PROJECTS \\
\hline re7 & Management and superior levels have been trained in formulation, assesment and pojects direction. \\
\hline re8 & $\begin{array}{l}\text { There exists an staff member in any enterprise that performs relative functions to assess and consolidate in the short-term of } \\
\text { the approved projects in order to attain the investment budgets inversión and financial needs. }\end{array}$ \\
\hline re9 & $\begin{array}{l}\text { La enterprises assess financially the investment decisions under the cash flow methodologies b determining financial criteria } \\
\text { such as the TIR and the VP. }\end{array}$ \\
\hline re10 & it is clearly established the annual rate that the investments rent and the enterprises do. \\
\hline re11 & $\begin{array}{l}\text { In the enterprises, we know how much the capital costs increase (known by the acronyms in English as WACC o weight } \\
\text { average capital cost) }\end{array}$ \\
\hline re12 & We have then follow-up processes and formal controls to the projects to be implemented. \\
\hline re13 & $\begin{array}{l}\text { we follow formal methodologies to prioritize projects given the multiple projects obtained of corporate entrepreneurial } \\
\text { processes not only based on investment budgets. }\end{array}$ \\
\hline \multirow[t]{2}{*}{ rc14 } & we reojice an wide work experience in the sectors in which enterprises are situated. \\
\hline & CORPORATE ENTREPRENEURIAL ACTIONS: NEW PRODUCTS, TECHNOLOGIES AND BUSINESSES \\
\hline ec1 & Most projects overpass the development stages and become a commcerical success. \\
\hline ec2 & the enterprise has invested meaningful resources in the last three years due to the development of products. \\
\hline ec3 & the income due to the sales of new products has gained participation in the total income during the las three couple of years. \\
\hline ec4 & new technologies have been implemented in the last three couple of years. \\
\hline ec5 & the enterprise has developed patents in the last three years, and the intellectual property is constantly growing. \\
\hline re6 & $\begin{array}{l}\text { the enterprise has invested meaningful resources in the last three years in the creation of new businesses different to those } \\
\text { traditional ones. }\end{array}$ \\
\hline re7 & incomes from new businesses have gained participation in the total income during the last three couple of years. \\
\hline re8 & $\begin{array}{l}\text { in the last three years, the income of international businesses has gained participation in the total income (corresponding to } \\
\text { exports, imports and investments aborad) }\end{array}$ \\
\hline
\end{tabular}

Source: Own elaboration. 
Table A.2

EO and CE Model Estimations and Impacts on the CE, by controlling SME by employees' size

\begin{tabular}{|l|c|c|}
\hline \multicolumn{1}{|c|}{ Efectos 0 Relaciones } & Less than 50 employees & More than 50 Employees \\
\hline Entrepeneurial orientation $\rightarrow$ Corporate Entrepreneurship actions & $0.401 * *$ & $0.842^{* * *}$ \\
Entrepreneurial orientation $\rightarrow$ Autonomy & $0.578^{* * *}$ & $0.489^{* * *}$ \\
Entrepreneurial orientation $\rightarrow$ Risk-taking & $0.694 * * *$ & $0.731^{* * *}$ \\
Entrepreneurial orientation $\rightarrow$ Proactivity & $0.801 * *$ & $0.782^{* * *}$ \\
Entrepreneurial orientation $\rightarrow$ Innovación willingness & $0.635^{* * *}$ & $0.632^{* * *}$ \\
Entrepreneurial orientation $\rightarrow$ Competitive Rivality & 0.337 & $0.474 * * *$ \\
\hline
\end{tabular}

Source: Own elaboration.

Table A.3

EO Model Estimations and Impacts on the CE mediated by the Capability of assessing and managing projects by controlling the SME by employees' size

\begin{tabular}{|c|c|c|}
\hline Effects and Relationships & Less than 50 employees & More than 50 Employees \\
\hline Entrepreneurial Orientation $\rightarrow$ Capability of assessing and managing projects. & $0,657^{7 * *}$ & $0.712 * *$ \\
\hline Capability of assessing and managing projects $\rightarrow$ Corporate Entrepreneurship actions. & 0,257 & $0.464 * * *$ \\
\hline Entrepreneurial Orientation $\rightarrow$ Capability of assessing and managing projects $\rightarrow$ Corporate Entrepreneurshi & 0,201 & $0.368^{* * *}$ \\
\hline Entrepreneurial Orientation $\rightarrow$ Autonomy & $0,693 * * *$ & $0.597 *$ \\
\hline Entrepreneurial Orientation $\rightarrow$ Risk-taking & $0,476^{* * *}$ & $0.537^{*}$ \\
\hline Entrepreneurial Orientation $\rightarrow$ Proactivity & $0,907 * * *$ & $0.893^{3 * *}$ \\
\hline Entrepreneurial Orientation $\rightarrow$ Innovation willingness & $0,479^{* * *}$ & $0.471^{1 * *}$ \\
\hline Entrepreneurial Orientation $\rightarrow$ Competitive Rivalry & 0,371 ** & $0.521 * * *$ \\
\hline
\end{tabular}

Source: Own elaboration. 
